\title{
Assessment of Safety Practices and Injuries Associated with Wood Processing in a Timber Company in Ghana
}

\author{
Stephen J. Mitchual*, Mark Donkoh, Francis Bih \\ Department of Construction and Wood Technology Education, University of Education, Winneba, Kumasi \\ Campus, Kumasi, Ghana \\ Email: ${ }^{*}$ Stephen.mitchual@yahoo.com
}

Received 15 February 2015; accepted 5 March 2015; published 6 March 2015

Copyright (C) 2015 by authors and Scientific Research Publishing Inc.

This work is licensed under the Creative Commons Attribution International License (CC BY). http://creativecommons.org/licenses/by/4.0/

(c) (i) Open Access

\section{Abstract}

This paper reports the assessment of safety practices and injuries in a timber company in Ghana. A cross-sectional survey design was used for the study. Data were collected from 300 respondents at a sawmill in Ghana using a 5-point Likert-type scale questionnaire. Descriptive and inferential statistics were used for the data analyses. The result indicates that the mean rating of the respondents on their use of personal protective equipment ranged from 1.09 to 2.51 . This implies that the workers of the sawmill rarely or never wear: gloves, overall, goggles, face shield, nose and mouth mask, earplugs or helmet during wood processing. Additionally, the mean ratings of the respondents regarding safety practices, machine and maintenance ranged from 2.42 to 4.03 with three out of the eight items having mean ratings higher than the theoretical mean of 3.0. The ratings of the respondents of the saw doctoring department on their practice of safety on machine and maintenance were significantly higher than those of the other departments. The result of the study further suggests that the workers of this sawmill do rarely report of: skin irritation/dermatitis, eye irritation, lack of appetite, arm/leg amputation, neck pains, hearing loss and poor eye sight problems. However, they usually report of headaches, nausea, respiratory problems, small cuts, back pains, and hip and leg pains. The outcome of this study therefore suggests that the management of the sawmill studied needs to do more to enforce practice of safety, especially the use of personal protective equipment, to reduce hazards and injuries associated with wood processing in the firm.

\section{Keywords}

Safety Practices, Wood Processing, Wood Processing Injuries, Woodworkers

\footnotetext{
"Corresponding author.
}

How to cite this paper: Mitchual, S.J., Donkoh, M. and Bih, F. (2015) Assessment of Safety Practices and Injuries Associated with Wood Processing in a Timber Company in Ghana. Open Journal of Safety Science and Technology, 5, 10-19. 


\section{Introduction}

Keeping the workplace safe must not be the concern of only workers and companies but also national and global economies whose productivity and competitiveness play a major role on safe working environment. The International Labour Organisation (ILO) considers issues relating to occupational health and safety (OHS) to be of much importance to the extent that it has devoted about $80 \%$ of its standards and instruments either wholly or partly to it [1]. This notwithstanding, currently around 160 million people are estimated to suffer from occupational diseases. Additionally, two million people die every year as a result of occupational accidents and workrelated diseases and injuries [2]. These numbers may translate into an estimate of nearly 5 percent loss of the world's GDP [1]. Furthermore, according to the World Health Organisation (WHO) as cited in [3], poor occupational health and reduced working capacity of workers may cause economic loss up to $10 \%$ - $20 \%$ of the Gross National Product of many countries for which Ghana is not an exception.

In Ghana the timber industry has been making substantial contribution to its economy over the years. As indicated by [4], the wood processing industry contributes about 11 percent of Ghana's foreign earnings, employs over 100,000 workers and provides a livelihood for over 2.5 million Ghanaians. However, the operations of the timber industry have been found to be associated with high levels of occupational hazards which result in illness and injuries. Records from the past two decades show that about 50 percent of fatal accidents in Ghana's industrial sector came from the wood working industry [5] [6]. According to [1], these figures may have been underestimated as nearly $50 \%$ of workplace injuries are not reported, especially in developing countries like Ghana. What the above suggests is that a lot of pragmatic steps need to be put in place to reduce occupational hazards so as to create a safe working environment and also improve the well-being of the workers in the wood processing industry.

Issues regarding OHS in Ghana are regulated by the Department of Factories Inspectorate. This department is responsible for promotion and enforcement of regulatory measures on OHS. In the absence of a national OHS policy in Ghana, the Factories, Offices and Shops Act of 1970, Workmen's Compensation Law, Act 187 (1987) and Labour Act 651 (2003) are the main legislative documents on OHS (Ghana News Agency, 2003) as cited in [7]. In spite of this, OHS has not attained a high profile in the sustainable development agenda of Ghana, where most of the working class is engaged in primary industries such as agriculture, logging, and mining [8]. This has resulted in high industrial-related accidents, injuries and diseases that cost Ghana about 7 percent of its GDP. Even though according to the Factories, Offices and Shop Act of 1970, all the stakeholders namely, the state, the employer and the employee have certain responsibilities, duties and obligations in reducing occupational hazards, the ultimate responsibility of safety practice rests on the worker/employee who directly experiences the effects of occupational hazards. Workers must follow established safety procedures and practice safety to ensure their own safety and good health as well as those of their co-workers. However, much is not known about the extent to which workers in the timber industry in Ghana consciously practice safety. Therefore, this paper seeks to assess the safety practices and injuries associated with wood processing in a timber company in Ghana so as to ascertain the safety culture in this company.

\section{Research Questions}

This study, which assessed the conformity to safety practices and injuries associated with wood processing at a timber processing firm in Ghana is guided by the following research questions:

1) How do woodworkers rate their practice of safety?

2) How does the department of woodworkers affect their rating of practice of safety?

3) How do woodworkers rate the effect of wood processing on their health?

4) How does the department of woodworkers affect their rating of effect of wood processing on their health?

\section{Research Methodology}

\subsection{Research Design}

A cross-sectional survey design was used for this study. According to [9], cross-sectional surveys are appropriate for situations where the data to be collected are about self-reported beliefs or behavior. Besides, it enables the researcher to collect data and compare many different variables at the same time without manipulating the study environment. 


\subsection{Population and Sample}

The population for this study comprised 702 workers of a selected sawmill in the Ashanti region of Ghana. This includes: 372 workers at the sawmill department, 221 workers at the veneering department, 92 workers at the moulding department, and 17 workers at the sawdoctoring department. Stratified random sampling technique was used to select respondents from the various departments of the selected company. The sample size was 426 and was determined in accordance with the mathematical formula: $\mathrm{n}=\mathrm{N} /\left(1+\mathrm{N}(\alpha)^{2}\right)$ where $\mathrm{n}=$ sample size; $\mathrm{N}=$ sampling frame; $\alpha=$ confidence level [7].

\subsection{Instruments}

The instrument used for the larger study was a questionnaire which was adapted from safety management perception questionnaire prepared by [10]. The questionnaire was made up of five (5) parts. The first part dealt with the demographic data of the respondents namely: gender, length of service, level of education, and department. The second part addressed issues on awareness of OHS by woodworkers of the selected company. The other three parts of the questionnaire assessed: 1) the willingness of the workers to use safety practice equipment 2) conformity to safety practices by the workers of the wood processing company, and 3) the effect of wood processing on the health of the woodworkers. The focus of this paper is on the conformity to safety practices by the workers of the wood processing company, and the effect of wood processing on the health of the woodworkers. With respect to conformity to safety practices, respondents were asked to indicate whether they never, rarely, sometimes, usually or always: "do wear gloves/mittens when working”, "do wear overall when working”, "do wear goggles when working”, "do wear face shield when working”, "do wear nose and mouth mask when working", "do wear earplugs or ear muffs when working", "do wear helmet when working” etc. On the issue of the effect of wood processing on the health of the woodworkers, respondents were asked to indicate whether they never, rarely, sometimes, usually or always report of: skin irritation/dermatitis, headaches, nausea, eye irritation, respiratory problems, lack of appetite etc. A pilot study was conducted to assess the validity (internal consistency) and reliability of the questionnaire in order to enhance its accuracy for assessment and evaluation. Participants for the pilot study were selected from four departments of the same company namely: veneering, sawmilling, moulding and sawdoctoring. They completed the sample questionnaire and in addition provided suggestions for its modification to help remove any ambiguity. The reliability of the questionnaire, which is concerned with its ability to measure consistently, was determined using the Cronbach's alpha. A Cronbach's alpha value of 0.78 which was obtained for the questionnaire was considered adequate.

\subsection{Data Collection Procedure}

The data for this part of the study was collected using a five-point Likert scale questionnaire at a single point in time. The questionnaire was administered by the researchers to the participants directly. A total number of about 426 questionnaires were distributed. The number of questionnaires successfully completed and returned were 300 (Sawmilling = 135; Veneering $=102$; Moulding $=52$; Sawdoctoring $=11$ ). This represents a return rate of about $70 \%$. According to Dillman (2000) as cited in [11], a return rate of $70 \%$ is a representative sample of the population. Participants were made to indicate their willingness to participate in the study. Directives on the questionnaires ensured respondents anonymity and confidentiality.

\subsection{Method of Data Analysis}

The data were analysed using descriptive and inferential statistics. Software used for the analysis was Statistical Package for Social Scientists (SPSS). The mean and standard deviation of the ratings for each of the items were computed, and the mean compared to the theoretical mean rating of 3.0 (assuming normal distribution of responses) to ascertain the respondents' perception on the themes studied. Additionally, the effects of department on the respondents' adherence to safety practices as well as injuries associated with wood processing were determined. An item-by-item one-way analysis of variance (ANOVA) at 5\% level of significance was performed to establish possible significant difference in the respondents' ratings of the factors of this study. P-values lower than 0.05 were deemed significant. In most of such situations Scheffe's post hoc test was used to make pair wise comparison of the means. 


\section{Results and Discussion}

\subsection{Woodworkers Practice of Safety}

Occupational health and safety can be important for several reasons, in that, good OHS practice can reduce employee injury and illness-related costs. Additionally, cost associated with sick leave and disability benefit can be reduced. Even though most of these costs could be prevented or significantly reduced through implementation of sound prevention, reporting and inspection practices they persist at various workplaces. Table 1 indicates the mean and the resultant mean ratings as well as their corresponding standard deviations of practice of safety by the respondents. The mean rating of the 300 respondents on the use of personal protective equipment ranged from $1.09(S D=0.548)$ for item \# 7 to $2.51(S D=1.013)$ for item \# 5 .

That of safety practices, machine and maintenance, ranged from $2.42(S D=1.826)$ for item \# 14 to 4.03 (SD $=1.549$ ) for item \# 10. The resultant mean rating of the respondents' practice of safety was $2.17(S D=1.343)$. Apart from three items ("do you ensure that guards and fences are in place when working”, "do you ensure that workers put off electrical gargets”, "do you ensure that workers maintain and repair machines”) for which the respondents' ratings were higher, all the other items had mean ratings lower than the theoretical mean of 3.0. This suggests that the workers of the sawmill studied rarely or never wear: gloves, overall, goggles, face shield, nose and mouth mask, earplugs or helmet during wood processing. Furthermore, the workers would rarely or never: insist that only trained personnel operate machines, ensure that workers adhere to safety rules, ensure that saws are adequately conditioned, and ensure that worn out chains and ropes are changed.

The rating of the respondents, especially on the use of personal protective equipment was a true reflection of what pertains at the sawmill used for the study. Indeed, most of the workers were either in "slippers" or "canvass" which do not protect their foot/toes (Figure 1). Additionally, almost all the workers were not in goggles, helmet, nose and mouth mask, overall (Figure 2), gloves/mittens or earplugs. This result is consistent with the outcome of a study conducted by [12] and [13]. In a study conducted on the theme "Awareness of Occupational Hazards, Health Problems and Safety Measures among Sawmill Workers in North Central Nigeria”, [12] concluded that less than $20 \%$ of the sawmill workers wore protective devices/clothing and this was due to the fact that health and safety standards were neither practiced nor enforced.

Table 1. Descriptive statistics on ratings of respondents on practice of safety.

\begin{tabular}{|c|c|c|c|}
\hline Item \# & Elements of safety practice & Mean rating $(\mathrm{n}=300)$ & Standard deviation \\
\hline & Personal protective equipment & & \\
\hline 1 & Do you wear gloves/mittens when working? & 1.72 & 1.082 \\
\hline 2 & Do you wear overall when working? & 1.10 & 0.520 \\
\hline 3 & Do you wear goggles when working? & 1.19 & 0.754 \\
\hline 4 & Do you wear face shield when working? & 1.14 & 0.651 \\
\hline 5 & Do you wear nose and mouth mask when working? & 2.51 & 1.013 \\
\hline 6 & Do you wear earplugs or ear muffs when working? & 1.22 & 0.720 \\
\hline \multirow[t]{2}{*}{7} & Do you wear helmet when working? & 1.09 & 0.548 \\
\hline & Machine and maintenance & & \\
\hline 8 & Do you ensure that guards and fences are in place when working? & 3.03 & 1.890 \\
\hline 9 & Do you ensure that trained personnel operate the machines? & 2.56 & 1.528 \\
\hline 10 & Do you ensure that workers put off electrical gargets? & 4.03 & 1.549 \\
\hline 11 & Do you ensure that workers adhere to safety rules? & 2.58 & 1.570 \\
\hline 12 & Do you ensure that workers maintain and repair machines? & 3.31 & 1.854 \\
\hline 13 & Do you ensure that saws are adequately conditioned? & 2.43 & 1.854 \\
\hline \multirow[t]{2}{*}{14} & Do you ensure that worn out chains and ropes are changed? & 2.42 & 1.826 \\
\hline & Resultant mean for elements of safety practice & 2.17 & 1.343 \\
\hline
\end{tabular}




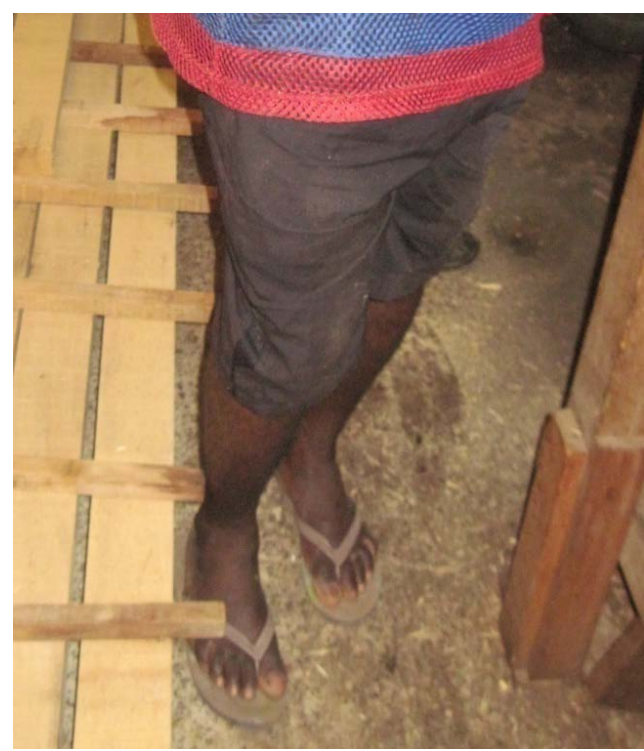

Figure 1. Picture of woodworker wearing bath room slippers whilst working.

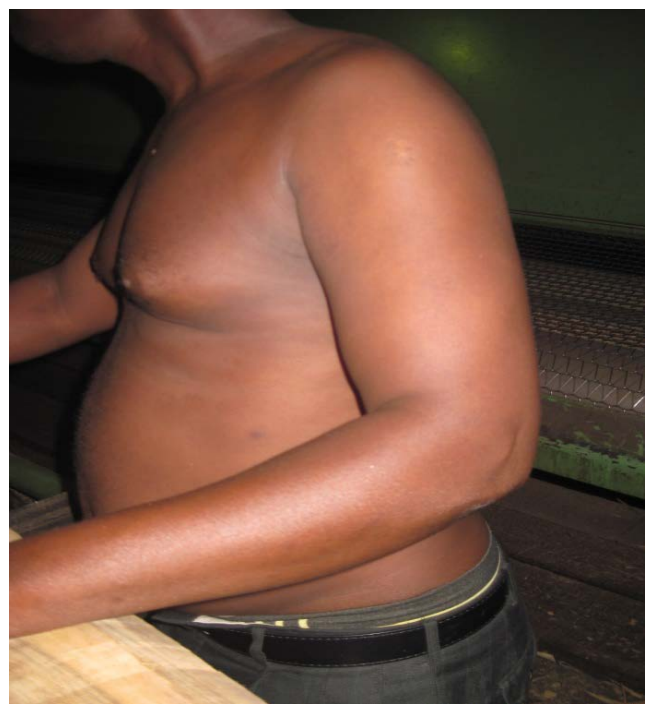

Figure 2. Picture of a worker neither in shirt or overall. He complained the environment was too warm.

A study by [13] on small scale sawmilling industries in Tamale Metropolis in Ghana also indicated that a significant number of the workers in the study area did not use personal protective equipment when operating machines or performing jobs that require their use. The non adherence to safety practices by the woodworkers would expose them to various degrees of hazards and injuries. For example, according to [14], many timber species contain chemicals that can irritate the eyes, nose and throat, causing shortness of breath, dryness and soreness of the throat and sneezing. Therefore, if workers do not adopt the use of the appropriate personal protective equipment they will expose themselves to various degrees of health problems and injuries.

\subsection{Comparison of Ratings of Departments on Practice of Safety by Woodworkers}

The effect of department on respondents' rating of their practice of safety is shown in Table 2. With the exception of the sawdoctoring department for which the mean rating of the respondents on item \# 3 was equal to the 
Table 2. ANOVA for the ratings of respondents' on practice of safety.

\begin{tabular}{|c|c|c|c|c|c|c|c|c|c|c|c|}
\hline \multirow[t]{2}{*}{ Item \# } & \multirow[t]{2}{*}{ Elements of safety practice } & \multicolumn{2}{|c|}{$\begin{array}{l}\text { Veneering } \\
\left(\mathrm{n}_{1}=102\right)\end{array}$} & \multicolumn{2}{|c|}{$\begin{array}{l}\text { Sawmilling } \\
\left(\mathrm{n}_{2}=135\right)\end{array}$} & \multicolumn{2}{|c|}{$\begin{array}{l}\text { Moulding } \\
\left(\mathrm{n}_{3}=52\right)\end{array}$} & \multicolumn{2}{|c|}{$\begin{array}{l}\text { Sawdoctoring } \\
\quad\left(\mathrm{n}_{4}=11\right)\end{array}$} & \multirow[t]{2}{*}{ F-value } & \multirow[t]{2}{*}{ p-value } \\
\hline & & Mean & $\mathrm{SD}$ & Mean & $\mathrm{SD}$ & Mean & $\mathrm{SD}$ & Mean & SD & & \\
\hline & Personal protective equipment & & & & & & & & & & \\
\hline 1 & Do you wear gloves/mittens when working? & 1.53 & 1.01 & 1.80 & 1.04 & 1.65 & 1.01 & 2.91 & 1.70 & 6.09 & $0.000^{*}$ \\
\hline 2 & Do you wear overall when working? & 1.12 & 0.55 & 1.10 & 0.56 & 1.00 & 0.00 & 1.36 & 0.81 & 1.63 & $0.182^{\dagger}$ \\
\hline 3 & Do you wear goggles when working? & 1.21 & 0.80 & 1.10 & 0.56 & 1.00 & 0.00 & 3.00 & 1.55 & 29.28 & $0.000^{*}$ \\
\hline 4 & Do you wear face shield when working? & 1.16 & 0.73 & 1.01 & 0.17 & 1.12 & 0.62 & 2.73 & 1.42 & 30.42 & $0.000^{*}$ \\
\hline 5 & $\begin{array}{l}\text { Do you wear nose and mouth mask when } \\
\text { working? }\end{array}$ & 2.48 & 1.08 & 2.58 & 0.93 & 2.46 & 1.06 & 2.18 & 1.17 & 0.65 & $0.582^{\dagger}$ \\
\hline 6 & $\begin{array}{l}\text { Do you wear earplugs or ear muffs when } \\
\text { working? }\end{array}$ & 1.20 & 0.77 & 1.24 & 0.74 & 1.15 & 0.54 & 1.45 & 0.82 & 0.59 & $0.619^{\dagger}$ \\
\hline \multirow[t]{2}{*}{7} & Do you wear helmet when working? & 1.10 & 0.59 & 1.10 & 0.61 & 1.00 & 0.00 & 1.18 & 0.60 & 0.60 & $0.615^{\dagger}$ \\
\hline & Machine and maintenance & & & & & & & & & & \\
\hline 8 & $\begin{array}{l}\text { Do you ensure that guards and fences are in } \\
\text { place when working? }\end{array}$ & 3.09 & 1.80 & 2.84 & 1.92 & 3.08 & 1.98 & 4.55 & 1.21 & 2.93 & $0.034^{*}$ \\
\hline 9 & $\begin{array}{l}\text { Do you ensure that trained personnel } \\
\text { operate the machines? }\end{array}$ & 2.85 & 1.42 & 2.33 & 1.53 & 2.46 & 1.64 & 3.09 & 1.58 & 2.81 & $0.040^{*}$ \\
\hline 10 & $\begin{array}{l}\text { Do you ensure that workers put off } \\
\text { electrical gargets? }\end{array}$ & 4.48 & 1.20 & 3.83 & 1.61 & 3.69 & 1.81 & 4.00 & 1.61 & 4.61 & $0.004^{*}$ \\
\hline 11 & $\begin{array}{l}\text { Do you ensure that workers adhere to safety } \\
\text { rules? }\end{array}$ & 2.75 & 1.34 & 2.40 & 1.65 & 2.54 & 1.71 & 3.55 & 1.57 & 2.40 & $0.068^{\dagger}$ \\
\hline 12 & $\begin{array}{l}\text { Do you ensure that workers maintain and } \\
\text { repair machines? }\end{array}$ & 3.91 & 1.55 & 3.00 & 1.92 & 2.81 & 1.91 & 3.91 & 1.87 & 6.88 & $0.000^{*}$ \\
\hline 13 & $\begin{array}{l}\text { Do you ensure that saws are adequately } \\
\text { conditioned? }\end{array}$ & 1.65 & 1.38 & 2.84 & 1.92 & 2.46 & 1.90 & 4.64 & 1.21 & 6.26 & $0.000^{*}$ \\
\hline 14 & $\begin{array}{l}\text { Do you ensure that worn out chains and } \\
\text { ropes are changed? }\end{array}$ & 1.82 & 1.55 & 2.74 & 1.89 & 2.58 & 1.91 & 3.27 & 1.68 & 15.37 & $0.000^{*}$ \\
\hline
\end{tabular}

*Statistically significant at 0.05 level of significance; ${ }^{\dagger}$ Not statistically significant at 0.05 level of significance.

theoretical mean of 3.0, all the other items under the use of personal protective equipment were rated less than the theoretical mean. It is also worth noting that all the item-by-item mean rating of the respondents in the department of sawdoctoring for practice of safety, that is, machine and maintenance was higher than the theoretical mean of 3.0. The rating of the respondents in this department for the practice of safety, machine and maintenance, ranged from 3.09 for item \# 9 to 4.64 for item \# 13. This result implies that the workers at the sawdoctoring department are more likely to usually or always enforce safety practices in respect of machine and maintenance as compared to those of the other departments who would never or rarely enforce such safety practices. The item-by-item one-way analysis of variance (ANOVA) shows that at 5\% level of significance, the department for which respondents belongs to significantly had effect on the rating of their use of personal protective equipment for the following items: "do you wear gloves/mittens when working", "do you wear goggles when working” and "do you wear face shield when working”.

Even though there were significant differences in the respondents' rating for the use of personal protective equipment for the items mentioned above, with the exception of the item "do you wear goggles when working" all the other items were rated lower than the theoretical mean of 3.0. This means that irrespective of the differences in the ratings of the respondents of departments, they would rarely or never wear gloves/mittens and face shield when working. On the contrary, the rating of the respondents on the following items: "do you wear overall when working”, "do you wear nose and mouth mask when working”, "do you wear earplugs or ear muffs when working" and "do you wear helmet when working" did not differ significantly.

With respect to practice of safety, machine and maintenance, apart from the item "do you ensure that workers 
adhere to safety rules”, the respondents' rating for all the other items differed significantly. To determine the items whose mean ratings differed significantly, an item-by-item Scheffe's post hoc multiple comparison of means was performed especially for the items whose mean ratings were higher than the theoretical mean of 3.0 (Item \# 8, 10, 12). The result shows that for item \# 8 there was a significant difference between respondents rating for sawmilling and sawdoctoring departments, with that of sawdoctoring being significantly higher than that of sawmilling department. In addition there was significant difference in the ratings of respondents in the veneering and sawmilling departments, and, veneering and moulding departments for items \# 10 and \# 12 respectively.

\subsection{Health Hazards and Injuries Associated with Wood Processing}

The result shown in Table 3 indicates the means of the respondents' ratings of health hazards and injuries associated with wood processing as well as their corresponding standard deviations. Table 3 also indicates the resultant mean ratings of the respondents. Seven out of the total number of 13 items were rated lower than the theoretical mean value of 3.0 and the ratings ranged from 1.10 to 2.99. This implies that the respondents do never or rarely report of: skin irritation/dermatitis, eye irritation, lack of appetite, arm/leg amputation, neck pains, hearing loss, and poor eye sight. On the contrary, six out of the total number of the 13 items were rated higher than the theoretical mean value of 3.0 and the ratings ranged from 3.08 to 3.40. This also suggest that on the average, the respondents would usually or always report of headaches, nausea, respiratory problems, small cuts, back pains, and hip and leg pains. Figure 3 and Figure 4 for instance are samples of pictures showing two workers who sustained various degrees of cut injuries during wood processing in the timber processing firm studied. Health hazards and injuries associated with wood processing have been a major problem in the timber industry worldwide.

Analysis of data collected from 60 respondents from three constituencies in the Tamale Metropolis in Ghana indicated: cut-type of injuries, fractures, sprains, catarrh, waist pains, eye problems and dizziness as the range of injuries and illness associated with wood processing [13]. Similar study by [12] also indicated that minor accidents constituted about $40.5 \%$ of the health problems that the workers experienced. Furthermore, [12] indicated that this was followed by stress and exhaustion after work (25.7\%) and eye irritation (14.0\%). What the above suggest is that the timber industry needs to do more to protect the health and safety of its employees since the human and economic costs of occupational accidents and diseases remain high and it requires concerted efforts to control them.

\subsection{Comparison of Ratings of Respondents in Departments Regarding Effect of Wood Processing on the Health of Woodworker}

The comparison of the respondents' ratings of health hazards and injuries associated with wood processing for the four departments is shown in Table 4. The result indicates that at 5\% level of significance, there was a significant difference in the ratings of the respondents on the occurrence of health problems and injuries related to wood processing for six of the items. Significant differences between the respondents' ratings occurred for the following items: “I do report of eye irritation”, "I do report of lack of appetite”, "have you ever had arm/leg amputation”, "I do report of back pains”, "I do report of hip and leg pains”, and "I do report of hearing loss”. For four of these items ("I do report of eye irritation”, "I do report of lack of appetite”, "have you ever had arm/leg amputation”, "I do report of hearing loss”) the mean ratings were generally lower than the theoretical mean of 3.0. What this means is that even though there were significant differences in the ratings of the departments, those health hazards would never or will rarely occur. In view of that Scheffe's post hoc multiple comparisons of means was performed for the items: "I do report of back pains" and "I do report of hip and leg pains".

The result for pair-wise comparison of means for the item \# 10 (I do report of back pains) indicated that the mean rating of the workers in the veneering $(\bar{x}=3.39)$, sawmilling $(\bar{x}=3.40)$ and the moulding $(\bar{x}=3.62)$ departments were significantly higher than that of the sawdoctoring department $(\bar{x}=2.45)$. This may be due to the fact that the nature of work in the three departments (veneering, sawmilling, moulding) requires a lot of standing and bending that could give rise to frequent pains at their back. The result for pair-wise comparison of means for item \# 11 also indicated that the mean rating of the workers in the moulding department $(x=3.46)$ was significantly higher than that of the sawdoctoring department $(\bar{x}=2.64)$. This may also be due to the same reason that the nature of work in the moulding department requires a lot of standing and bending that could result in frequent hip and leg pains. 
Table 3. Descriptive statistics on ratings of respondents' on effect of wood processing on the health of woodworkers.

\begin{tabular}{|c|c|c|c|}
\hline Item \# & Elements of health hazards of wood processing on woodworkers & Mean rating $(\mathrm{n}=300)$ & Standard deviation \\
\hline & Exposure to sawdust & & \\
\hline 1 & I do report of skin irritation/dermatitis & 2.25 & 1.122 \\
\hline 2 & I do report of headaches & 3.38 & 1.252 \\
\hline 3 & I do report of nausea & 3.13 & 0.846 \\
\hline 4 & I do report of eye irritation & 2.57 & 1.346 \\
\hline 5 & I do report of respiratory problems & 3.08 & 1.030 \\
\hline \multirow[t]{2}{*}{6} & I do report of lack of appetite & 1.49 & 0.909 \\
\hline & Exposure to cutting sharp edge & & \\
\hline 7 & I do report of small cuts & 3.27 & 0.981 \\
\hline \multirow[t]{2}{*}{8} & Have you ever had arm/leg amputation & 1.10 & 0.514 \\
\hline & Heavy lifting injury & & \\
\hline 9 & I do report of neck pains & 2.99 & 1.076 \\
\hline 10 & I do report of back pains & 3.40 & 0.888 \\
\hline \multirow[t]{2}{*}{11} & I do report of hip and leg pains & 3.35 & 0.862 \\
\hline & Noise/poor ventilation injuries & & \\
\hline 12 & I do report of hearing loss & 1.35 & 0.810 \\
\hline \multirow[t]{2}{*}{13} & I do report of poor eye sight & 1.77 & 1.003 \\
\hline & $\begin{array}{l}\text { Resultant mean for the elements of health hazard of wood processing on } \\
\text { woodworkers }\end{array}$ & 2.55 & 0.993 \\
\hline
\end{tabular}

Table 4. ANOVA for ratings of respondents' of wood processing effect on the health of woodworkers.

\begin{tabular}{|c|c|c|c|c|c|c|c|c|c|c|c|}
\hline \multirow[t]{2}{*}{ Item \# } & \multirow{2}{*}{$\begin{array}{l}\text { Wood processing effect on the } \\
\text { health of woodworkers }\end{array}$} & \multicolumn{2}{|c|}{$\begin{array}{l}\text { Veneering } \\
\left(\mathrm{n}_{1}=102\right)\end{array}$} & \multicolumn{2}{|c|}{$\begin{array}{l}\text { Sawmilling } \\
\left(\mathrm{n}_{2}=135\right)\end{array}$} & \multicolumn{2}{|c|}{$\begin{array}{l}\text { Moulding } \\
\left(\mathrm{n}_{3}=52\right)\end{array}$} & \multicolumn{2}{|c|}{$\begin{array}{l}\text { Sawdoctoring } \\
\quad\left(\mathrm{n}_{4}=11\right)\end{array}$} & \multirow[t]{2}{*}{ F-value } & \multirow[t]{2}{*}{ p-value } \\
\hline & & Mean & SD & Mean & SD & Mean & SD & Mean & $\mathrm{SD}$ & & \\
\hline & Exposure to sawdust & & & & & & & & & & \\
\hline 1 & I do report of skin irritation & 2.31 & 1.08 & 2.21 & 1.11 & 2.27 & 1.21 & 2.09 & 1.30 & 0.252 & $0.860^{\dagger}$ \\
\hline 2 & I do report of headaches & 3.25 & 1.06 & 3.52 & 1.30 & 3.37 & 1.39 & 2.91 & 1.58 & 1.417 & $0.238^{\dagger}$ \\
\hline 3 & I do report of nausea & 3.19 & 0.73 & 3.16 & 0.88 & 3.06 & 0.85 & 2.55 & 1.21 & 2.120 & $0.098^{\dagger}$ \\
\hline 4 & I do report of eye irritation & 2.77 & 1.31 & 2.43 & 1.35 & 2.35 & 1.34 & 3.45 & 1.13 & 3.419 & $0.018^{*}$ \\
\hline 5 & $\begin{array}{l}\text { I do report of respiratory } \\
\text { problems }\end{array}$ & 3.10 & 0.91 & 3.19 & 1.06 & 2.79 & 1.16 & 2.91 & 0.94 & 1.988 & $0.116^{\dagger}$ \\
\hline \multirow[t]{2}{*}{6} & I do report of lack of appetite & 1.53 & 0.93 & 1.39 & 0.85 & 1.46 & 0.85 & 2.36 & 1.29 & 4.109 & $0.007^{*}$ \\
\hline & Exposure to cutting sharp edge & & & & & & & & & & \\
\hline 7 & I do report of small cuts & 3.22 & 0.75 & 3.38 & 1.08 & 3.15 & 1.07 & 3.09 & 1.14 & 1.012 & $0.388^{\dagger}$ \\
\hline \multirow[t]{2}{*}{8} & $\begin{array}{l}\text { Have you ever had arm/leg } \\
\text { amputation }\end{array}$ & 1.07 & 0.35 & 1.07 & 0.43 & 1.15 & 0.67 & 1.55 & 1.29 & 3.336 & $0.020^{*}$ \\
\hline & Heavy lifting injury & & & & & & & & & & \\
\hline 9 & I do report of neck pains & 3.14 & 0.90 & 2.88 & 1.17 & 3.06 & 1.07 & 2.55 & 1.21 & 1.804 & $0.147^{\dagger}$ \\
\hline 10 & I do report of back pains & 3.39 & 0.80 & 3.40 & 0.87 & 3.62 & 0.91 & 2.45 & 1.29 & 5.402 & $0.001^{*}$ \\
\hline \multirow[t]{2}{*}{11} & I do report of hip and leg pains & 3.36 & 0.79 & 3.35 & 0.82 & 3.46 & 0.98 & 2.64 & 1.12 & 2.865 & $0.037^{*}$ \\
\hline & Noise/poor ventilation injuries & & & & & & & & & & \\
\hline 12 & I do report of hearing loss & 1.38 & 0.80 & 1.21 & 0.66 & 1.46 & 0.94 & 2.09 & 1.38 & 4.892 & $0.002^{*}$ \\
\hline 13 & I do report of poor eye sight & 1.82 & 1.01 & 1.69 & 0.94 & 1.77 & 1.06 & 2.36 & 1.29 & 1.687 & $0.170^{\dagger}$ \\
\hline
\end{tabular}

*Statistically significant at 0.05 level of significance; ${ }^{\dagger}$ Not statistically significant at 0.05 level of significance. 


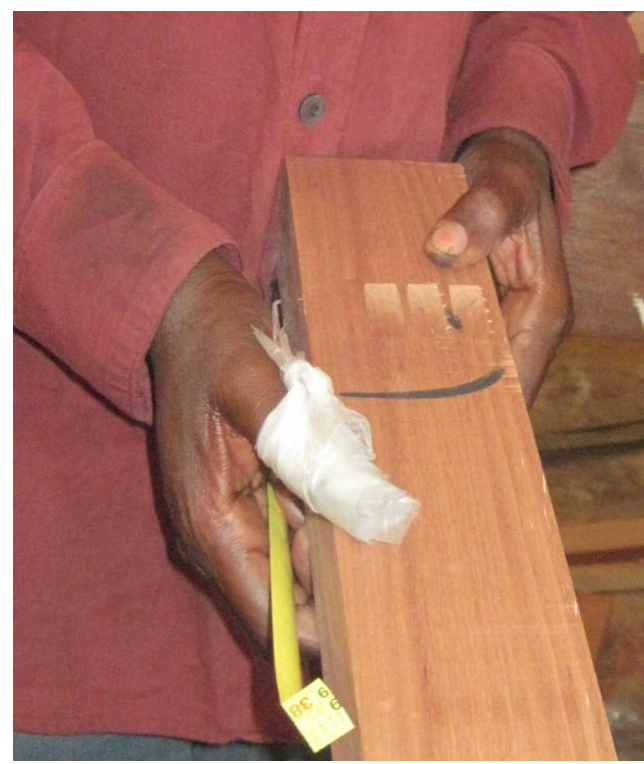

Figure 3. Picture of a woodworker with a minor cut.

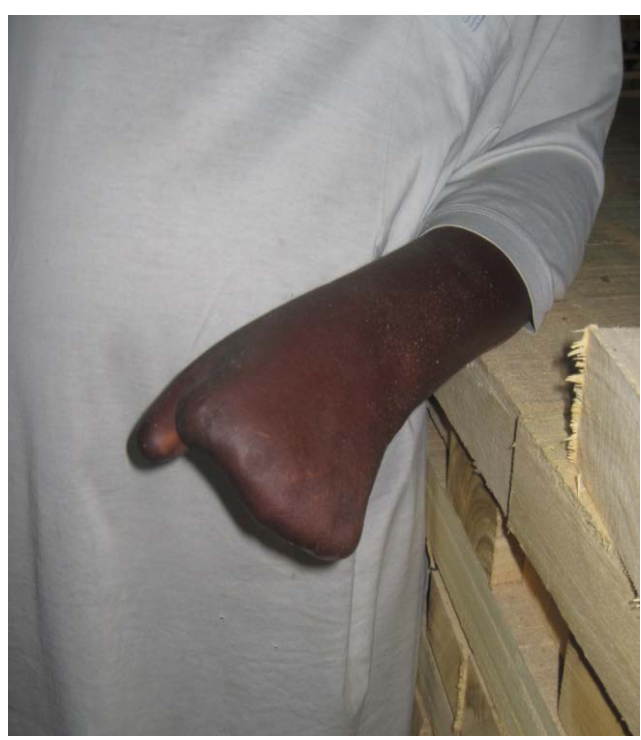

Figure 4. Picture of a woodworker with all the fingers cut-off during operation of a machine without prior training.

\section{Conclusion and Recommendation}

Studies conducted in other parts of the world suggest that the wood industry is exposed to high levels of occupation hazards. This in no doubt affects the social well-being of the workers, their families as well as the economies of this industry. In view of the above, this study was conducted to assess the safety practices and injuries associated with a wood processing company in Ghana. The study found that the workers of the timber firm studied would rarely or never wear: gloves, overall, goggles, face shield, nose and mouth mask, earplugs or helmet during wood processing. Additionally, the workers would rarely or never: insist that only trained personnel operate machines; ensure that workers adhere to safety rules; ensure that saws are adequately conditioned; and ensure that worn out chains and ropes are changed. The workers at the saw doctoring department are also more likely to enforce safety practices on machine and maintenance as compared to those of the other departments. It 
could further be concluded from the study that the workers of this sawmill do rarely report of: skin irritation/ dermatitis, eye irritation, lack of appetite, arm/leg amputation, neck pains, hearing loss and poor eye sight. Nevertheless, they usually report of headaches, nausea, respiratory problems, small cuts, back pains, and hip and leg pains. It is therefore recommended that occupational health and safety practices should be promoted in the sawmill studied through adoption of good health and safety practice as a personal and organisational value.

\section{Acknowledgements}

The authors are grateful to the management of the timber firm used for the study. Our appreciation also goes to the workers for willingly accepting to be part of this study. Special thanks also go to Mr. Francis Donkor of the Department of Mechanical Technology Education, University of Education for his professional advice during the preparation of the instrument for the study.

\section{References}

[1] Alli, B.O. (2008) Fundamental Principles of Occupational Health and Safety. 2nd Edition, International Labour Office, Geneva.

[2] ILO (2013) Health and Safety at Work: Facts and Figures. http://www.ilo.org/global/about-the-ilo/media-centre/issue-briefs/WCMS_206117/lang--en/index.htm

[3] Amponsah-Tawiah, K. and Dartey-Baah, K. (2011) Occupational Health and Safety: Key Issues and Concerns in Ghana. International Journal of Business and Social Science, 2, 119-126.

[4] Acquah-Moses, E.K. (2002) Supply to the Local Market: From Policy to Chain Saw Lumber Production Production a Necessary Evil? Troperbs International-Ghana Workshop, Proceeding 2, Wood Industries Training Centre, Akyawkrom, Ejisu, Kumasi.

[5] Boateng, M. and Nimako, M. (2000) A Situational Analysis of Occupational Health and Safety in Ghana. Unpublished Draft Report, Ministry of Employment and Social Welfare, Accra, 15-22.

[6] Ministry of Health, Ghana Health Services (2002) A Handbook of Occupational Health. Occupational and Environmental Health Unit, Accra.

[7] Adei, D. and Kunfaa E.Y. (2007) Occupational Health and Safety Policy in the Operation of the Wood Processing Industry in Kumasi, Ghana. Journal of Science and Technology, 27, 161-173.

[8] Amponsah-Tawiah, K. (2013) Occupational Health and Safety and Sustainable Development in Ghana. International Journal of Business Administration, 4, 74-78. http://dx.doi.org/10.5430/ijba.v4n2p74

[9] Neuman, W.L. (2000) Social Research Methods: Qualitative and Quantitative Approaches. Allynn \& Bacon, Boston.

[10] Lapidus, R.A. and Waite, M.J. (2001) Safety Management Perception Questionnaire. http://www.sipeonlinetraining.com/A-ZResources/Safety\%20Management\%20Perception\%20Survey.pdf

[11] Bright Ideas (2009) How Many Is Enough? The Quest for an Acceptable Survey Response Rate. https://kkbiersdorff.wordpress.com/2009/09/16/how-many-is-enough/

[12] Osagbemi, G.K., La-Kadri, R.T. and Aderibigbe, S.A. (2010) Awareness of Occupational Hazards, Health Problems and Safety Measures among Sawmill Workers in North Central Nigeria. TAF Preventive Medicine Bulletin, 9, 325328.

[13] Ochire-Boadu, K., Kusi, E. and Lawer, E.A. (2014) Occupational Hazards and Safety Practices: A Concern among Small Scale Sawmilling Industries in Tamale Metropolis, Ghana. International Journal of Scientific \& Technology Research, 10, 234-236.

[14] Ahman, M., Holmstrom, M., Cynkier, I. and Soderman, E. (1996) Work Related Impairment of Nasal Function in Swedish Woodwork Teachers. Occupational and Environmental Medicine, 53, 112-117.

http://dx.doi.org/10.1136/oem.53.2.112 